\title{
The Evaluation of Recession Magnitudes in EU Countries during the Great Recession 2008-2010
}

\section{Jiř́ Mazurek ${ }^{1}$}

\begin{abstract}
The aim of this article is to compare 2008-2010 recession magnitudes in individual EU countries. For the comparison the recession magnitude scale was used. The strongest recession during the examined period took place in Latvia, Estonia, Lithuania, Greece and Ireland, while the weakest recessions in the EU occurred in France, Malta and Cyprus. Poland and Slovakia were the only two EU countries that didn't fall into a recession, that's why they were not included in the study. The main findings of the paper are that EU19's recession was much smaller than both the Great Depression of the 1930s and the recent Great Recession in the USA. Furthermore, with the use of a linear econometric model it was found that recession magnitudes in EU countries were directly proportional to the countries' GDP per capita in 2008 and growth prior to recessions, while countries' economic openness was indirectly proportional to recession magnitudes, all the relationships being statistically significant.
\end{abstract}

Key words: European Union, global financial crisis, recession, recession classification, recession magnitude.

JEL Classification: JEL: C23, E32, O52

Received: 6 March 2016 / Accepted: 30 August 2016 / Sent for Publication: 16 September 2016

\section{Introduction}

The global financial crisis that started in summer 2007 in the USA was an unprecedented event in the last decades. Its size and depth is often compared to the Great Depression of the 1930s, that is why it was dubbed 'the Great Recession' by some experts (Arpaia and Curci, 2010). The crisis had some common characteristics with recessions of the past: it was preceded by a long period of rapid credit growth, low risk premiums, abundant availability of liquidity, strong leveraging, soaring asset prices and the development of bubbles in the real estate sector (Buti, 2009).

The crisis was triggered by an acute liquidity shortfall among financial institutions, but a collapse of a financial sector seemed largely unlikely at the beginning. However, the situation changed after the bankruptcy of major US investment banks Merrill Lynch and Lehman Brothers on $14^{\text {th }}$ and $17^{\text {th }}$ of September 2008 respectively. Investors liquidated their assets, stock markets dramatically dropped and a downturn spiral began to whirl. During a few months many banks, especially in the USA, followed the fate of Lehman

\footnotetext{
${ }^{1}$ Silesian University in Opava, School of Business Administration in Karvina , Univerzitní nám. 1934/3, Karviná,mazurek@opf.slu.cz.

(C) 2016 by the authors; licensee Review of Economic Perspectives / Národohospodářský obzor, Masaryk University, Faculty of Economics and Administration, Brno, Czech Republic. This article is an open access article distributed under the terms and conditions of the Creative Commons Attribution 3.0 license, Attribution - Non Commercial - No Derivatives.
} 
Brothers. ${ }^{2}$ This development led to a fall of large financial institutions around the globe or their bailout by national governments; some countries found themselves on the brink of financial breakdown too.

In the European Union, the recession started in the $1^{\text {st }}$ quarter of 2008 in Estonia, Ireland, Latvia and Sweden (Eurostat, 2011). The European Union as a whole fell into a recession in the $2^{\text {nd }}$ quarter of 2008 and returned back to the growth after more than one year, in the $3^{\text {rd }}$ quarter of 2009. At the end of 2010 EU19 fell into another recession lasting until the first quarter of 2013.

During 2008-2010, EU's GDP contracted by approximately $5.5 \%$ when compared to the GDP level prior to the recession (Eurostat, 2011). The unemployment in EU was the lowest $(6.8 \%)$ in the $2^{\text {nd }}$ quarter 2008 , but reached almost $10 \%$ in November 2009 (Arpaia and Curci, 2010) The EU's reaction to the economic downturn was to stabilize, restore and reform of the banking sector and to launch the European Economic Recovery Plan (EERP) in December 2008 based on two pillars: to boost demand and stimulate confidence by a major injection of purchasing power (1.5\% of EU's GDP) into the economy, and to reinforce Europe's competitiveness in the long term (Communication from the Commission to the European Council - A European Economic Recovery Plan, 2008). The overall fiscal stimulus from EERP amounted to $5 \%$ GDP of EU (Buti, 2009). Many EU countries adopted their own anti-crisis policies that included cuts in government spending, reforms of the banking and public sector, and revisions of pension and tax systems. During 2009 and 2010 the EU provided a massive financial aid ${ }^{3}$ to Greece's and Ireland's indebted economies. For a detailed analysis of the crisis causes or consequences see e.g. Arpaia and Curci (2009), Buti (2009), Newson (2009) or Remond-Tiedrez (2009).

However, crisis impacts in EU were not distributed uniformly through its member states. Many experts (Krugman, 2008 and IMF Survey Magazine, 2010) noticed that the most suffering countries included that of Baltic region (Latvia, Lithuania and Estonia), Ireland and Greece. After a short recovery during 2010, many EU countries (Italy, Spain, Czech Republic, Portugal or Denmark), including EU19, fell into another (not so deep) recession in the 2011-2013 period, which was followed by a modest growth in 2014 and 2015.

This paper focuses on a comparison of recession magnitudes in individual EU countries during 2008-2010 period. Recessions are often compared by various macroeconomic indicators such as GDP decline, duration, unemployment rates, fall of industrial production, downturn of stock market indices, decrease in trade volumes or real personal income and many others (Moore, 1967, Barufaldi, 2008, Gascon, 2009, or Eichengreen and O'Rourke, 2010). Mutual dependence of economic indicators during business cycles in European countries was studied, for example in Falk and Sinabell (2009) or Gaggl et al. (2009). The recent global financial crisis is often compared with the Great

\footnotetext{
${ }^{2}$ According to the Federal Deposit Insurance Corporation (FDIC), more than 300 banks were closed in the USA during 2009 and 2010 , (http://www.fdic.gov/bank/individual/failed/banklist.htm).

${ }^{3}$ The EU-IMF financial package for Greece' economy reached 110 billion euros (IMF Survey Magazine, May 9, 2010) and 85 billion euros for Ireland (IMF Survey Magazine, December 16, 2010).
} 
Depression from the 1930s, which represents a standard of a severe economic recession, sometimes with contradictory results (see e.g.: Barufaldi, 2009, Buti, 2009, Eichengreen and O'Rourke, 2010). The problem of a recession comparison inheres in the fact that when many indicators are involved, a direct comparison of recessions' strength becomes inconclusive in general. One recession may be evaluated worse by one indicator but better by another. The use of a recession magnitude scale presented in Section 2 provides a possible solution to this problem.

The aim of the article is to compare recession magnitudes in 25 out of 28 current EU countries. Slovakia and Poland were not included in the study, because they avoided an economic recession in the examined period, and Croatia was not a member of EU until 2013. Also, for the examination of a statistical relationship between the recession magnitude and a set of selected economic variables an econometric model is introduced and tested.

The paper is organized as follows: in Section 2 recession magnitude scale and recession classification is introduced, in Section 3 the data and the method are described, recession comparisons and the econometric model are presented in Section 4; Conclusions close the article.

\section{Recession magnitude}

A recession is defined as a period when GDP declines for at least two consecutive quarters. Hence GDP decline and recession duration are the most important and also the most cited indicators relevant to the recession magnitude. The measure of the recession magnitude was introduced by Mazurek and Mielcová (2013):

DEFINITION: Let $D$ be the number of consecutive quarters with negative quarterly changes in real GDP. Let $p_{1}, p_{2}, \ldots, p_{\mathrm{D}}$ be (negative) percentage changes from the preceding period in real GDP for the respective $D$ quarters, $\left|p_{i}\right|<100$. Let the mean percentage decline $G$ of real GDP for the respective $D$ quarters be given as:

$$
G=100-\sqrt[D]{\prod_{i=1}^{D}\left(100+p_{i}\right)} .
$$

Then the recession magnitude scale is a mapping $(D, G) \rightarrow M$ such that:

$$
\begin{gathered}
M=\log _{2}(10 D G)=\frac{\log (10 D G)}{\log 2}=\frac{\log D+\log G+1}{\log 2} . \\
\text { where } D \geq 2 \text { and } G \geq 0.1 .
\end{gathered}
$$

Constraints (3) result directly from the definition of recession and from the convention of using one decimal place in GDP growth rates values. The value of $\mathrm{M}$ for the lowest possible values of $D$ and $G$ is equal to 1 . Moreover, (2) implies that $M$ increases by 1 point ('one order of magnitude') if $D$ doubles and $G$ isn't changed and vice versa. A recession with the magnitude $M=5$ is twice as strong as a recession with the magnitude $M=4$. 
If only yearly GDP growth rates are available, relations (1) to (3) can be easily modified so that a duration $D$ of a recession is given in years and $G$ is equal to the geometric mean of annual GDP growth rates; $D \geq 1$ and $G \geq 0.1$. However, the use of quarterly GDP data is more precise because the period of a recession given in years may not describe its actual duration accurately.

The existence of the recession magnitude scale allows defining several classes of recessions with respect to their magnitudes. The categories are as follows (Mazurek a Mielcová, 2013):

- $\quad$ Minor recession $(1 \leq M<5)$,

- Major recession $(5 \leq M<7)$,

- $\quad$ Severe recession $(7 \leq M<9)$,

- $\quad$ Ultra recession $(9 \leq M)$.

These categories were proposed to unify the terminology expressing the "strength" of a recession.

\section{The data and the method}

For the comparison of recession magnitudes in 25 EU countries (without Poland, Slovakia and Croatia) Eurostat's quarterly GDP growth rates series adjusted for inflation and seasonality (Eurostat 2011) from 2008 to 2010 were used. Due to possible later GDP revisions, all the data for EU countries are provided in Table 1.

For a comparison of EU19's recession magnitude with the magnitude of the Great Depression in the 1930s yearly GDP growth rates from the US Bureau of Economic Analysis (2010) were used and are presented in Table 2.

For a multiple linear regression in Section 4 the following data and data sources for aforementioned $25 \mathrm{EU}$ countries were employed:

- $\quad$ GDP per capita in 2008 from World Bank (2015).

- Economic openness defined as a ratio of a trade to GDP in \% from World Bank (2016) national accounts, expressed as an average value from 2008, 2009 and 2010.

- $\quad$ Mean GDP growth during the 2003-2007 period from Eurostat (2011).

- $\quad$ Population from OECD (2010). 
Table 1 Gross domestic product, volumes; percentage change q/q-1 of EU countries from 2007 to 2010

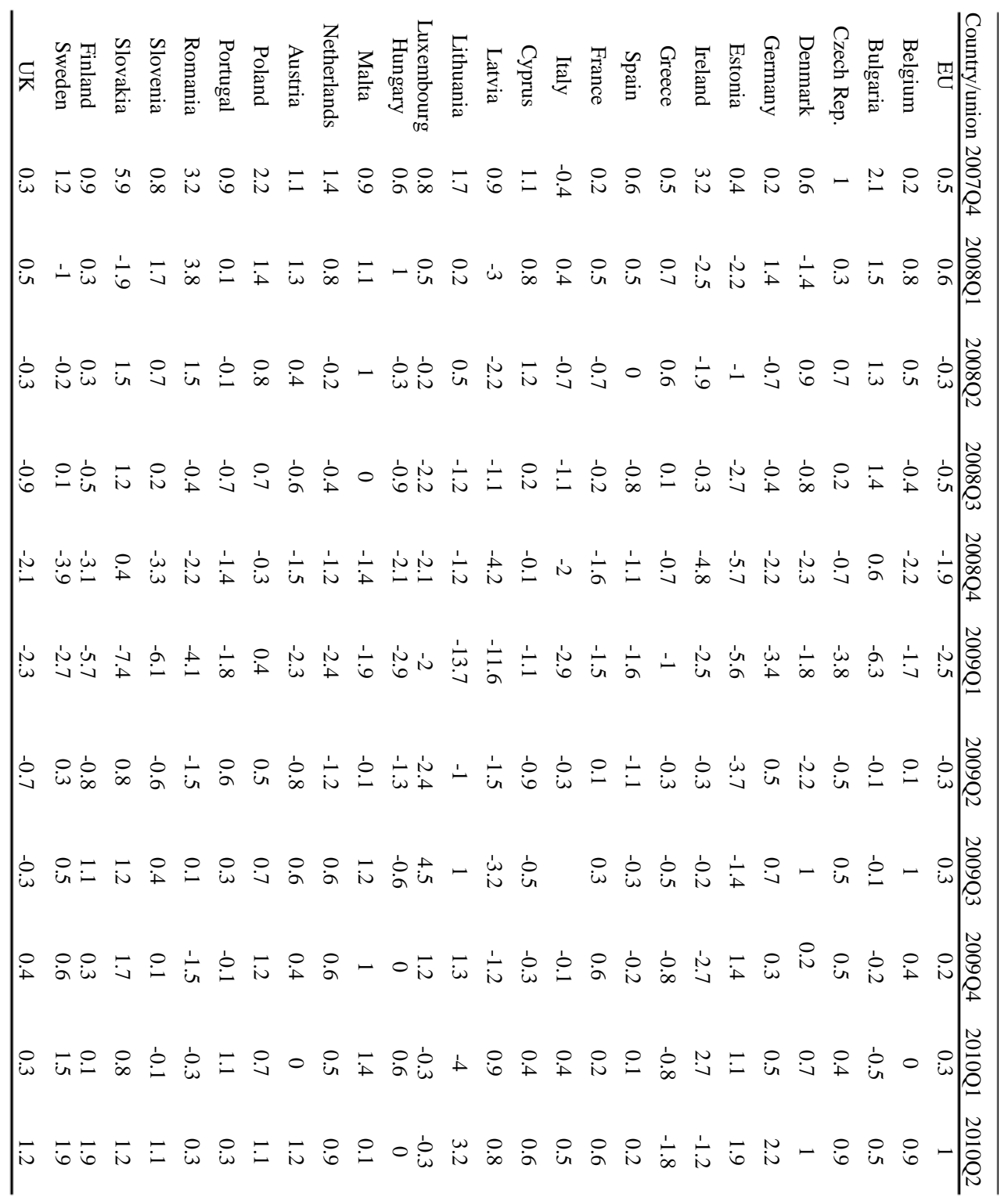

Source: Eurostat (2011). 
A statistical relationship between recession magnitude and the set of four explanatory (independent) variables (GDP per capita, economic openness, mean GDP growth 20032007 and population) was examined by a multiple linear model, which takes the following general form:

$$
y_{i}=\beta_{0}+\beta_{1} x_{i 1}+\beta_{2} x_{i 2}+\ldots+\beta_{n} x_{i n}+\varepsilon_{i} .
$$

In (4) $y_{i}$ denotes dependent variable, $x_{i}$ are independent (explanatory variables or regressors) variables, $n$ is the number of independent variables, $i$ denotes $i$-th observation, $\beta$ are parameters to be estimated and $\varepsilon_{i}$ are the error terms (residuals).

Table 2 Percentage changes in real GDP from the preceding period, USA, 1929-1934.

\begin{tabular}{lllllll}
\hline Year & 1929 & 1930 & 1931 & 1932 & 1933 & 1934 \\
\hline GDP (\%) & 6.4 & -12.0 & -16.1 & -23.3 & -3.9 & 17 \\
\hline
\end{tabular}

Source: Bureau of Economic Analysis (2010).

\section{Results}

\subsection{Recession magnitudes in EU countries}

Since 2008, 25 EU countries experienced a recession. Figure 1 illustrates the economic development in major EU economies from 2008 to 2010, with the lowest dip in GDP growth rates occurring in the first quarter of 2009.

Recession magnitudes in EU countries were estimated by relations (1) and (2), the complete results are provided in Table 3 . Figure 2 illustrates geographical distribution of recessions. The biggest recessions occurred in Latvia $(\mathrm{M}=8.2)$, Greece $(\mathrm{M}=8.0)$, Estonia $(\mathrm{M}=7.8)$, Lithuania $(\mathrm{M}=7.5)$ and Ireland $(M=7.3)$, all five recessions were classified as severe recessions. The majority of remaining recessions was classified as major recessions. The smallest recession took place in Cyprus $(M=4.9)$, Malta $(M=$ $5.1)$, and France $(M=5.3)$; thus, Cyprus' recession was the only recession of minor category. EU as a whole experienced recession of the magnitude 5.8, this recession falls into the major category. The most of recessions were U-shaped, Swedish recession was W-shaped and Greek L-shaped.

The Greek, Irish and Latvian recession were among the longest, they lasted for 13, 8 and 8 consecutive quarters respectively. The deepest recession with the highest mean decline of GDP growth rates during a recession took place in Lithuania $(G=4.4 \%)$. These results conform to the opinions published by Andersen (2009), Krugman (2008) or IMF Survey magazine (2010) about the most affected regions and countries within the European Union.

Interestingly, six out of ten the most affected countries belong to new EU members (see Table 3); and at the top of the table prevail small and open economies, indicating that smaller economies might be more vulnerable in the times of a crisis. Also, recession magnitudes were higher for countries that grew faster in years prior to the crisis, but were rather under EU average in terms of GDP per capita. These relationships are examined in more detail in section 4.2. 
The reasons for Latvian (and Baltic region generally) infamous primacy rest upon 'overheating' of the Latvian economy in years prior to the crisis, when its economy grew by more than $10 \%$ of GDP annually and private external debt reached $130 \%$ GDP; however, the country was losing its competitiveness meanwhile (for details see Andersen [2009]), and after the crisis broke up, foreign capital was withdrawn from the country, thus contributing to the decline.

The causes of the infamous Greek recession were mainly unsustainable public and private debts in the wake of 2008, a weak political system and mismanagements of its government, and also a structural weakness of the Greek economy, see Kouretas and Vlamis (2010). The existence of the common currency, Euro, contributed to the crisis as well.

Ireland expanded rapidly during 1995-2007 as it introduced very low corporate tax rates and ECB interest rates, but its banking sector got under pressure after the property bubble bursting and the start of the global financial crisis in 2007.

The world-wide recession that started in 2008 naturally attracts comparisons with other well-known recessions of the past. One of the most famous recessions is the Great Depression in the USA. The Great Depression officially began in the USA on October 29, 1929, as the Wall Street stock market crashed, and ended in 1934. During the Great Depression, the unemployment rate peaked at $25 \%$, GDP declined by more than $50 \%$, and industrial production decreased by $45 \%$ (Bernanke, 2001). During the Great Depression, the mean yearly decline of GDP was $14.1 \%$. From relations (1) and (2), and with the use of the data shown in Table 2, the magnitude of the Great Depression was estimated to be $M=9.14$. This result implicates that the Great Depression in the USA during 1929-1933 was more than eight times worse than the recession in the European Union of 2008-2009. Recent 2008-2009 recession in the USA, based on Eurostat (2011) data, reached $M=7.4$, a higher value than for $E U$, but much smaller value when compared to 1929-1934 depression.

Figure 1 Time evolution of quarterly GDP growth rates of major EU economies and EU itself during 2008-2010 global financial crisis.

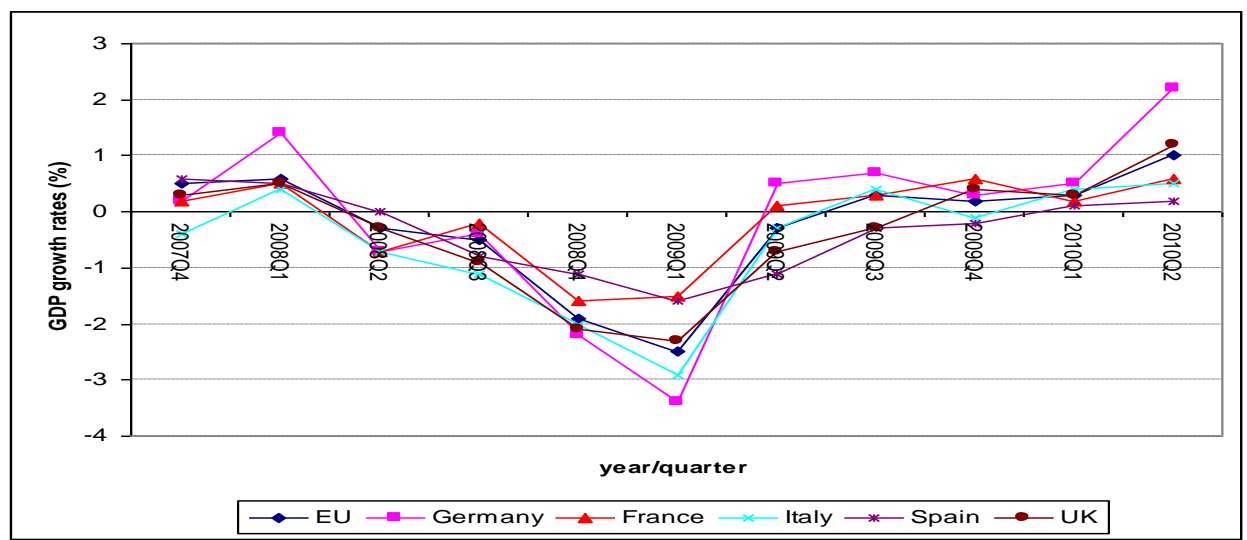

Source: Eurostat (2011). 
Table 3 Magnitudes and classification of all EU recessions during 2008-2010.

\begin{tabular}{|c|c|c|c|c|}
\hline Country & $\begin{array}{c}\text { Mean decline of GDP } \\
(\%)\end{array}$ & Duration (quarters) & Magnitude & Classification \\
\hline Latvia & 3.56 & 8 & 8.15 & severe \\
\hline $\begin{array}{c}\text { Greece } \\
(2010-2013)\end{array}$ & 2.00 & 13 & 8.03 & severe \\
\hline Estonia & 3.20 & 7 & 7.81 & severe \\
\hline Lithuania & 4.44 & 4 & 7.47 & severe \\
\hline Ireland & 1.91 & 8 & 7.26 & severe \\
\hline Finland & 2.55 & 4 & 6.67 & major \\
\hline Slovenia & 3.36 & 3 & 6.66 & major \\
\hline Luxembourg & 1.78 & 5 & 6.48 & major \\
\hline Romania & 2.06 & 4 & 6.36 & major \\
\hline Hungary & 1.35 & 6 & 6.34 & major \\
\hline Sweden & 1.55 & 5 & 6.28 & major \\
\hline Bulgaria & 1.45 & 5 & 6.18 & major \\
\hline Denmark & 1.78 & 4 & 6.15 & major \\
\hline $\begin{array}{c}\text { Greece } \\
(2008-2009)\end{array}$ & 1.77 & 4 & 6.14 & major \\
\hline Italy & 1.40 & 5 & 6.13 & major \\
\hline Germany & 1.68 & 4 & 6.07 & major \\
\hline UK & 1.10 & 6 & 6.05 & major \\
\hline Netherlands & 1.08 & 5 & 5.76 & major \\
\hline Austria & 1.30 & 4 & 5.70 & major \\
\hline Spain & 0.85 & 6 & 5.67 & major \\
\hline Czech R. & 1.68 & 3 & 5.65 & major \\
\hline Belgium & 1.44 & 3 & 5.43 & major \\
\hline Portugal & 1.00 & 4 & 5.33 & major \\
\hline France & 1.00 & 4 & 5.32 & major \\
\hline Malta & 1.14 & 3 & 5.09 & major \\
\hline Cyprus & 0.58 & 5 & 4.86 & minor \\
\hline
\end{tabular}

Notes: The second Greek recession began in 2010 and continued until 2013 (beyond the scope of the study), but it was included in the table for a comparison.

Source: author. 
Figure 2 The geographic distribution of recession magnitudes across Europe.

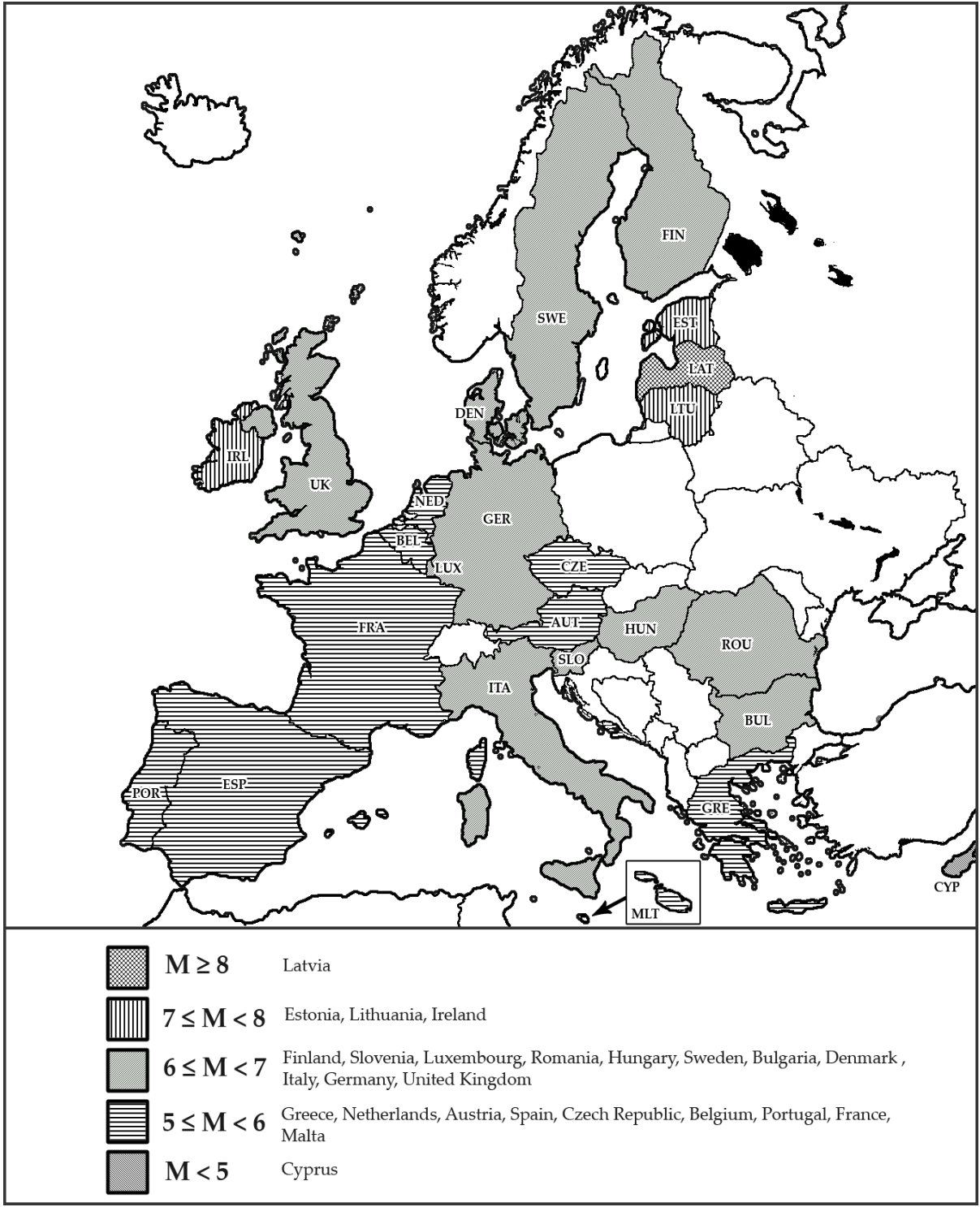

Source: author.

\subsection{An econometric model}

In this section the statistical relationship between recession magnitudes and the set of four economic variables is examined by a multiple linear regression model.

The dependent variable of the model: 
- The recession magnitude in 25 EU countries provided in Table 3 (abbreviated as $\mathrm{M})$.

Independent variables of the model:

- GDP per capita in 2008 in USD (abbreviated as GDP),

- $\quad$ Economic openness in \% (OPEN),

- $\quad$ Mean GDP growth during 2003-2007 period in \% (GROWTH),

- The logarithm of a population (LOG(POP)).

The data are provided in the Appendix. The model takes the form:

$$
M_{i}=\beta_{0}+\beta_{1} G D P 2008_{i}+\beta_{2} O_{P P N}+\beta_{3} G R O W T H_{i}+\beta_{4} L O G(P O P)_{i}+\varepsilon_{i}
$$

The number of observations $n=25$.

Correlation matrix of all variables is provided in Table 4. The most correlated variables were the recession magnitude and growth prior to a recession. This correlation was positive, which means countries that experienced higher economic growth before 2008 also suffered stronger subsequent recession (the correlation was statistically significant at 0.05 level).

Multicollinearity of the model was tested with the use of variance inflation factor VIF, see e.g. O'Brian (2007), where $V I F \geq 10$ indicates a multicollinearity. The largest value of VIF was for the variable OPEN $(V I F=1.58)$, hence the multicollinearity in the model was not a problem. Also, the test for normality of residuals was performed in Gretl, with the result the normality cannot be rejected $(p=0.24)$. Therefore, the estimation of the model (5) was performed by OLS method with corrected heteroscedasticity via statistical software Gretl.

Results are provided in Table 5. The model fitted the data very well, with the adjusted coefficient of determination $R^{2}=0.917$.

Although a list of countries with the highest recession magnitudes is topped by rather small and less populated countries, see Table 3, the logarithm of the population was found statistically insignificant in the model (5). Nevertheless, the remaining three regressors were found statistically significant at 0.05 (OPEN variable) or 0.01 level (GDP and GROWTH variables) respectively. However, the quantitative effect of OPEN and GDP variables was rather small, see Table 5. The recession magnitude is higher for countries which experienced higher economic growth prior to the recession, and also for countries with higher GDP per capita at the beginning of the crisis. Figure 3 illustrates the relationship between the recession magnitude and the growth before the crisis. Somewhat surprisingly, the economic openness was found indirectly proportional to the recession magnitude, though, usually, open economies are considered more vulnerable. However, Haddad et al. (2013) argue that when a trade is well diversified, the volatility decreases in fact, which might provide at least partial explanation of this result. 
Table 4 The correlation matrix of all variables in the model (5).

\begin{tabular}{|l|c|c|c|c|c|}
\hline & LOG(POP) & OPEN & M & GROWTH & GDP \\
\hline LOG(POP) & 1 & -0.678 & -0.200 & -0.437 & -0.066 \\
\hline OPEN & & 1 & 0.062 & 0.184 & 0.475 \\
\hline M & & & 1 & 0.706 & -0.126 \\
\hline GROWTH & & & & 1 & -0.401 \\
\hline GDP & & & & & 1 \\
\hline
\end{tabular}

Source: author

Table 5 The results of the model (5) estimation by OLS method with corrected heteroscedasticity.

\begin{tabular}{|l|c|c|c|c|}
\hline Variable & Coefficient & Error & p-value & Significance \\
\hline const & 3.949 & 1.457 & 0.0135 & $* *$ \\
\hline LOG(POP) & 0.119 & 0.193 & 0.544 & \\
\hline OPEN & -0.0046 & 0.00215 & 0.0474 & $* *$ \\
\hline GROWTH & 0.375 & 0.0276 & $<0.00001$ & $* * *$ \\
\hline GDP & $1.472 \mathrm{e}-05$ & $4.479 \mathrm{e}-06$ & 0.0037 & $* * *$ \\
\hline
\end{tabular}

Source: author

Figure 3 A relationship between the mean GDP growth during 2003-2007 and the recession magnitude for EU countries.

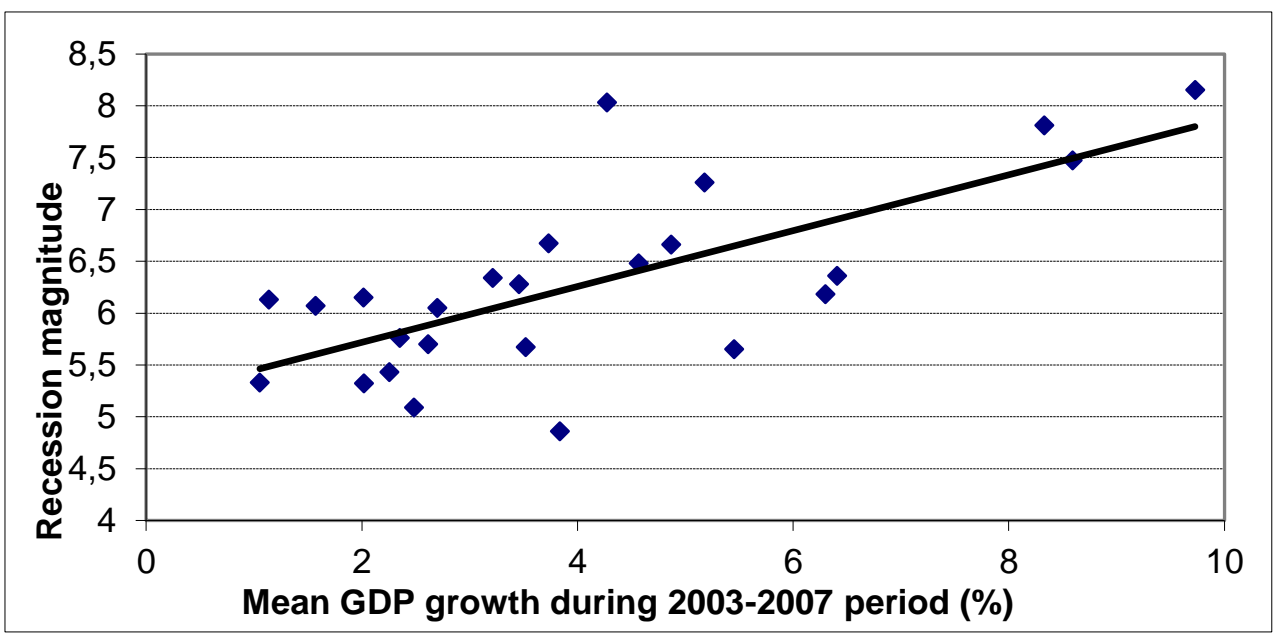

Source: author 


\section{Conclusions}

The aim of the article was to compare magnitudes ('strength') of recessions that took place in EU countries during the first phase of the global financial crisis, and to examine statistical relationship between recession magnitudes and a set of four selected economic variables.

The main findings of the study include confirmation that the most affected countries by the crisis were Balkans countries, Greece and Ireland, and generally countries of the European periphery. Secondly, EU19 recession during 2008-2010 was much smaller when compared to the Great Depression in the USA in 1929-1934 or 2008-2009 Great Recession. Finally, from the econometric model in Section 4 it followed that recession magnitudes in individual EU countries were directly proportional to their growth prior to the crisis and GDP per capita in 2008, and indirectly proportional to their economic openness.

Funding: This paper was supported by the Ministry of Education, Youth and Sports within the Institutional Support for Long-term Development of a Research Organization in 2016.

Disclosure statement: No potential conflict of interest was reported by the author.

\section{References}

Andersen, C. (2009). Latvia Caught in Vicious Economic Downturn. IMF Survey Magazine: Countries and Regions. Available from: http://www.imf.org/external/pubs/ft/survey/so/2009/car 052809a.htm). [Accessed: 25 September 2011].

Arpaia, A., Curci, C. (2010) EU labour market behaviour during the Great Recession. Econ Papers 405.

Barufaldi, D. (2008) A Review of Past Recessions. Investopedia. Available from: http://www. investopedia.com/articles/economics/08/past-recessions.asp. [Accessed 30 September 2011].

Bernanke, B.S. (2001). Essays on the Great Depression. Princeton University Press.

Bureau of Economic Analysis (2010). Available from: http://www.bea.gov. [Accessed 30 September 2011].

Buti, M. (ed.). (2009). Economic crisis in Europe: Causes, Consequences and Responses. European Economy 7, Luxembourg.

Communication from the Commission to the European Council - A European Economic Recovery Plan. (2008). Brussels. Available from:

http://ec.europa.eu/economy_finance/publications/publication13504_en.pdf. [Accessed 4 October 2011].

Eichengreen, B., O'Rourke, K. (2010). What do the new data tell us. VOX 3. Available from: http://www.voxeu .org/index.php?q=node/3421. [Accessed 30 September 2011]. 
Eurostat (2011). Available from:

http://epp.eurostat.ec.europa.eu/portal/page/portal/eurostat /home/. [Accessed 12 September 2011].

Falk, M., Sinabell, F. (2009). A spatial econometric analysis of the regional growth and volatility in Europe. Empirica 36(2), pp. 193-207 DOI: 10.1007/s10663-008-9078-Z

Gaggl, P., Kaniovski, S., Prettner, K., Url, T. (2009). The short and long-run interdependencies between the Eurozone and the USA. Empirica 36(2), pp. 209-227.

Gascon, C.S. (2009). The Current Recession: How Bad Is It? Econ Synopses 4:1-2. Available from: http://research.stlouisfed.org/publications/es/09/ES0904.pdf. [Accessed: 2 October 2011].

IMF Survey Magazine: Countries and Regions (2010). After Severe Recession, Stabilization in Latvia. Available from: http://www.imf.org/external/ pubs/ft/survey/so/2010/car021810a.htm. [Accessed 30 September 2011].

Haddad, M, Lim, J. J., Pancaro, C., Saborowski, C. (2013). Trade openness reduces growth volatility when countries are well diversified, Canadian Journal of Economics, Volume 46, Issue 2, pp. 765-790. DOI: 10.1111/caje.12031

Kouretas, G. P., Vlamis, P. (2010). The Greek Crisis: Causes and Implications. Panoeconomicus, 4, pp. 391-404. DOI: 10.2298/PAN1004391K

Krugman, P. (2008). European Crass Warfare. The New York Times. Available from: http://www.nytimes.com /2008/12/15/opinion/15krugman.html. [Accessed 12 October 2011].

Mazurek, J., Mielcová, E. (2013). The Evaluation of Economic Recession Magnitude: Introduction and Application, Prague Economic Papers 2013(2), pp. 182-205. DOI: $\underline{10.18267 / j . p e p .447}$

Moore, G.H. (1967). What is a Recession? Amer. Stat., 21, pp. 16-19.

Newson, B. (2009). Recession in the EU-29: Length and Depth of the Downturn Varies Across Activities and Countries. Eurostat: Industry, Trade and Services 97. Available from: http://epp.eurostat.ec.europa.eu/cache/ITY_OFFPUB/KS-SF-09-097/EN/KS-SF09-097-EN.PDF. [Accessed 28 September 2011].

O'Brian, R. M. (2007). A Caution Regarding Rules of Thumb for Variance Inflation Factor. Quality and Quantity, 41, pp.673-690. DOI: 10.1007/s11135-006-9018-6

OECD (2010). 2010 Annual statistics. Available from:

https://data.oecd.org/pop/population.htm.

Rémond-Tiedrez, I. (2009). Recession in the EU-27: output measures. Eurostat - Statistics in focus 17/2009.

World Bank (2015). Available from:

http://data.worldbank.org/indicator/NY.GDP.PCAP.CD/ countries?display=default. [Accessed 12 April 2016].

World Bank (2016). Available from:

http://data.worldbank.org/indicator/NE.TRD.GNFS.ZS. . [Accessed 12 April 2016]. 


\section{Appendix}

The input data for the model (5).

\begin{tabular}{|c|c|c|c|c|c|}
\hline Country & LOG(POP) & OPEN & GROWTH & GDP & M \\
\hline Austria & 6.923 & 95.87 & 2.615 & 51386.4 & 5.7 \\
\hline Belgium & 7.035 & 148.79 & 2.256 & 48424.6 & 5.43 \\
\hline Bulgaria & 6.879 & 109.2 & 6.299 & 7296.1 & 6.18 \\
\hline Cyprus & 6.042 & 103.77 & 3.835 & 34950.4 & 4.86 \\
\hline Czech Rep. & 7.021 & 122.52 & 5.453 & 22649.4 & 5.65 \\
\hline Denmark & 6.743 & 95.61 & 2.015 & 64182.0 & 6.15 \\
\hline Estonia & 6.127 & 132.65 & 8.331 & 18094.5 & 7.81 \\
\hline Finland & 6.728 & 77.71 & 3.733 & 53401.3 & 6.67 \\
\hline France & 7.798 & 53.35 & 2.019 & 45413.1 & 5.32 \\
\hline Germany & 7.913 & 76.97 & 1.572 & 45699.2 & 6.07 \\
\hline Greece* & 7.053 & 53.3 & 4.274 & 31997.3 & 8.03 \\
\hline Hungary & 7 & 154.63 & 3.212 & 15649.7 & 6.34 \\
\hline Ireland & 6.65 & 174.57 & 5.178 & 61189.7 & 7.26 \\
\hline Italy & 7.781 & 50.86 & 1.138 & 40659.7 & 6.13 \\
\hline Latvia & 6.352 & 95.98 & 9.727 & 16323.8 & 8.15 \\
\hline Lithuania & 6.522 & 121.32 & 8.594 & 14961.6 & 7.47 \\
\hline Luxembourg & 5.7 & 325.85 & 4.566 & 112851.5 & 6.48 \\
\hline Malta & 5.617 & 169.27 & 2.483 & 20895.8 & 5.09 \\
\hline Netherlands & 7.219 & 129.728 & 2.352 & 56928.8 & 5.76 \\
\hline Portugal & 7.027 & 66.78 & 1.054 & 24815.6 & 5.33 \\
\hline Romania & 7.332 & 66.34 & 6.408 & 10136.5 & 6.36 \\
\hline Slovenia & 6.311 & 124.63 & 4.871 & 27501.8 & 6.66 \\
\hline Spain & 7.663 & 51.53 & 3.520 & 35578.7 & 5.67 \\
\hline Sweden & 6.97 & 87.8 & 3.457 & 55746.8 & 6.28 \\
\hline UK & 7.793 & 58.11 & 2.700 & 45195.2 & 6.05 \\
\hline
\end{tabular}

Source: author.

Notes: Out of two Greek recessions, the recession with the higher magnitude was used for the evaluation. 